\title{
Protective effect of Moringa oleifera and green tea aqueous extract in combination against beta-cyfluthrin induced mutagenicity in albino rats
}

\author{
Mohamed A. Noaishi \\ Mammalian Toxicology Department, Central Agricultural Pesticides Lab. (CAPL), \\ Agricultural Research Center, Ministry of Agriculture, Egypt.
}

Email: noaishi@gmail.com

\begin{abstract}
The present work was designed to investigate the mutagenicity effect of beta-cyfluthrin in bone marrow of male albino rats and the protective role of the combined aqueous extract of dried leaves of Moringa oleifera (MO) and green tea (GT). Twenty adult male rats were divided randomly into 4 groups, each containing five rats per group. The route of administration was orally gavage for 28 consecutive days. Rats in Group (a) were given distilled water and served as control, rats in Group (b) were given beta-cyfluthrin at a dose of $6.75 \mathrm{mg} / \mathrm{kg}$ b.wt (1/20 of estimated LD50). Rats in Group (c) were given aqueous extract of $(\mathrm{MO}+\mathrm{GT})$ as the only source of drinking fluid, for 28 days. Rats in Group (d) were given the same doses of group (b) and enabled continuously to an aqueous of (MO+GT) extract as the only source of drinking fluid. Animals were sacrificed humanely at the end of study. The micronucleus and chromosomal aberrations assays were used as mutagenicity tests. The results showed that beta-cyfluthrin administration alone increased the frequency of micronucleated polychromatic erythrocytes (MNPCEs) and induced several of chromosomal aberrations (CAs) in bone marrow cells of treated rats compared to control group. While the aqueous extract of (Mo+GT) in combination against the mutagenic potential of beta-cyfluthrin significantly decrease the (MNPCEs) and (CAs). In conclusion, this study confirmed the genotoxic potential of beta-cyfluthrin but also revealed the strong protective effect of aqueous leaves extract of Moringa oleifera and Green tea in combination as anti-mutagenic agents.
\end{abstract}

Key Words: Beta-cyfluthrin, rat, chromosomal aberrations, micronucleus assay, Moringa oleifera, Green tea.

\section{Introduction}

Synthetic pyrethroid insecticides have been used for last decades to control insect pests in agriculture and public health sectors for mosquito control, housefly and other household insects. Pyrethroid insecticides are classified into two types; type I and type II depend on the chemical structure and the toxicity (WHO, 2005). Beta-cyfluthrin is a type II pyrethroid and one of the most commonly insecticides used in agricultural and household applications. Cyfluthrin is a first generation of this pyrethroid insecticide while Beta-cyfluthrin is a second generation and is content of stereoisomers of cyfluthrin. Because of gene-mutation and resistance induction in some insect-pests, cyfluthrin has been decrease in their own killing 
power (Chandre et al., 1999). Thus, it was urgent to manufacture second generation of this pyrethroid, which has more efficacy against insects. Beta-cyfluthrin is two to five times higher in toxicity to insects than cyfluthrin (EC, 2002). While, cyfluthrin was found to have a weak genotoxic and cytotoxic effect in in vitro assays, the mammalian test systems or in vivo assays showed potential genotoxic effects (Ila et al., 2008). Likewise, beta-cyfluthrin showed increased in the potential genotoxic effects in bone marrow cells and hepatic damage in mice (Verma et al., 2013). Also (Marinowic et al., 2012) found that beta-cyfluthrin had genotoxic effects in native fish species after a sublethal exposure by using comet assay technique. More addition, (Mohafrash et al., 2016) reported that sub-chronic exposure to beta-cyfluthrin induced liver, kidney and testicular damage in male rats. Therefore, people who exposure to beta-cyfluthrin during occupational exposure or in household application, or indirect exposure via insecticides residues in air, water and food may be at risk. On the other hand, during the last decades, there has been a strong evidence proved that dietary consumption of some vegetables, plant products caused reduction of the harmful effects of different toxicants and environmental pollutants (Nandi et al., 1997). Moringa oleifera, especially their leaves, were found to be an excellent source of natural antioxidants, which-contained vitamins, flavonoids, minerals, and other compounds that are considered to have health beneficial effects (Anwar et al., 2007) and (Moodley, 2017). Moringa oleifera dried leaves extract were also found to have strong properties as antimutagenic, anticarcinogenic, anti-inflammatory, and antifungal activity (Rao et al., 2001) and (Sathya et al., 2010). However, the bitter and herbal taste of aqueous dried leaf extract of Moringa oleifera is considered non-palatable for many people. These findings suggest that any good additives to this aqueous solution could improve the bitter taste and may lead to increase the palatability of drinking the aqueous extract of Moringa oleifera leaves. Green tea, which became a traditional drink to many people around the world and have a good taste (Ntila et al., 2019), can be additive to Moringa oleifera aqueous extract to obtain a good taste of drinking solution. In addition, several previous investigations demonstrated that green tea (GT) and its main substances have protective effects against a broad range of environmental or chemical toxins. The preventive and curative effect of its components was mainly related to their anti-oxidative, scavenging, radical catching, and antiapoptotic properties (Rameshrad et al., 2017). Therefore, the present work is designed to evaluate the capability of beta-cyfluthrin insecticide to induce mutagenic effect in rat bone marrow cells after 28 days of repeated exposure. At the same time, to evaluate the possible protective role of aqueous extract of both Morenga olivera and green tea dried leaves in combination to ameliorate the mutagenic effects of the test insecticide.

\section{MATERIALS AND METHODS}

\section{Animals:}

Twenty healthy male albino rats (Rattus norvegicus) of Wistar strain weighing $120 \mathrm{~g} \pm 10 \%$ were used throughout the whole study. The animals obtained from Mammalian and Aquatic Toxicology department, Central Agricultural Pesticides Lab, Giza., Egypt. Animals were kept under full hygiene standards, had free access to clean water and have a well-balanced fresh diet, and were kept under the supervision for one week before the experimental work began. 
The animals were housed in all groups of five rats per cage. Procedures for animals and their care were carried out in accordance with the ethical guidelines for laboratory animals of Mammalian and Aquatic Toxicology Department.

\section{Insecticide (Beta-Cyfluthrin):}

The test insecticide used in this study was a commercial insecticide with active ingredients of beta-cyfluthrin 10\%, (the IUPAC name (RS)-a-cyano-4-fluoro-3-phenoxybenzyl (1RS,3RS;1RS,3SR)-3-(2,2-dichlorovinyl)-,2-dimethylcyclo-propane-carboxylate).

The formulation was supplied as suspension concentrate (SC). The test substance was prepared in sterile distilled water. The dose was selected based on preliminary study, which had been performed to determine the LD50 of beta-cyfluthrin formulation.

\section{Preparation of M. oleifera and green tea aqueous extract:}

Moringa oleifera and green tea dried leaves were obtained from local distributor, in Agriculture Research Center, Giza, Egypt. The mixture of aqueous extract of M. oleifera and green tea was prepared by soaking $10 \mathrm{~g}$ of each M. oleifera and green tea dried leaves to be in total $20 \mathrm{~g}$ in $1 \mathrm{~L}$ of boiling distilled water. The temperature did not increase above $90{ }^{\circ} \mathrm{C}$, for 5 min to obtain the decoction of dried leaves. The technique described early by (Maity et al., 1998), and later adopted by (El-Beshbishy, 2005). The solution was filtered to obtain the final $2 \%(\mathrm{w} / \mathrm{v}) \mathrm{M}$. oleifera and green tea aqueous extract. This solution was substituted in the place of water as the only source of drinking fluid.

\section{Experimental design:}

Rats were randomly divided into four groups each containing 5 animals per cage. The route of administration of the study was orally gavage for 28 consecutive days. Rats in Group (a) kept as control and were given distilled water $(1 \mathrm{ml} / \mathrm{rat})$ as reference daily dose and allowed freshwater ad libitum. Rats in Group (b) were given beta-cyfluthrin at a dose of $6.75 \mathrm{mg} / \mathrm{kg}$ b.wt. daily which equivalent to 1/20 of estimated LD50 (data not shown) and allowed fresh water at ad libitum. Rats in Group (c) were given aqueous extract of M. oleifera and green tea dried leaves (MO+GT) as the only source of fluid for drinking solution for 28 days. Rats in Group (d) were given the same doses of group (b) and enabled continuously to an aqueous of $(\mathrm{MO}+\mathrm{GT})$ extract as the only source of drinking solution. During the experimental duration, body weights were recorded, and the administrated doses modulated according to weekly body weight gain.

\section{Mutagenicity assays:}

Cytogenetic assays are carried out routinely to determine the mutagenic ability of test chemicals. The micronucleus test (MNs) in bone marrow cells serves as an important endpoint to detect the genetic damage by chemicals in the cells of the organisms. In addition, the identification of chromosomal damage provides a method for checking the genotoxic effects of chemical substances. At the end of the experiment, all rats were humanely killed under light ether anesthesia. Both femurs were excised out and, the bone marrow cells were collected 
from both femurs for mutagenicity assays. The frequency of micronucleated polychromatic erythrocytes (PCEs) in bone marrow preparations were scored and analyzed according to the protocol described by (Krishna \& Hayashi, 2000). The technique of rat chromosome aberrations in bone marrow was conducted using a procedure defined earlier by (Adler, 1984) with some modifications was suggested by (Noaishi et al., 2013).

\section{Statistical analysis}

The statistical analysis was done by using SigmaPlot statistics software, Ver.11. One-way ANOVA analysis followed by Duncan's test was used. The differences were statistically significant at $\mathrm{p}<0.05$. All data were expressed as Mean \pm Standard Error (SE).

\section{Results and Discussion}

The obtained data in Table1 show that the test insecticide beta-cyfluthrin induced a potential genotoxicity effect in the bone marrow of treated rats, after repeated administration $(6.75$ $\mathrm{mg} / \mathrm{kg}, 28$ days) by the significant increase in the total number of micronucleated polychromatic erythrocytes (PCEs) in comparison with the control group. In all treatment groups the frequencies of polychromatic erythrocytes (PCEs) which having one micronucleus $(\mathrm{MN})$ and two micronuclei (MNs) were more than those having three micronuclei, when compared to control group. On the other hand, the protective effect of the combined uptake of $\mathrm{MO}+\mathrm{GT}$ extract as the only source of drinking fluid decrease the PCEs with (MNs) than those scored in control group. More addition the group administrated beta-cyfluthrin as the same in group (b) and uptake of MO+GT extract as the only source of drinking fluid did not scored significant increase of the (MNs) in this treatment group. Likewise, the results of chromosome aberrations in table 2 show that repeated administration of beta-cyfluthrin induced significant increase in the total number of aberrant cells. It is also evident that repeated administration with beta-cyfluthrin caused an increase in the frequencies of chromatid gaps(tg), chromatid break(tb), end to end association(E-E), and chromosomes translocation(C-T). However, it is obvious that the concomitant administration of beta-cyfluthrin with the combination of $\mathrm{MO}+\mathrm{GT}$ extract significantly decreased the total number of aberrant cells in comparison with the control group. Moreover, the individual administration of MO+GT extract alone as the only source of drinking fluid had the strong anti-mutagenic effect by reducing the frequency of chromosome aberrations than that recorded in control group. The photographs of rat's bone marrow, showing some types of micronucleated polychromatic erythrocytes (MNPCEs) and some types of chromosome aberrations (CAs) illustrated in figure (1). 
Table 1: The numbers of micronuclei frequency in rats bone marrow cells after treatments groups

\begin{tabular}{|c|c|c|c|c|c|}
\hline \multirow{2}{*}{ Treatments } & \multicolumn{3}{|c|}{$\begin{array}{l}\text { No. of micronuclei in the } \\
\text { PCEs }\end{array}$} & \multirow{2}{*}{$\begin{array}{c}\text { Total No. of } \\
\text { micronucleated } \\
\text { polychromatic } \\
\text { erythrocytes (PCEs) }\end{array}$} & \multirow{2}{*}{ Mean \pm S.E } \\
\hline & 1 & 2 & $\geq 3$ & & \\
\hline Control group & 14 & 4 & 2 & 18 & $4.40 \pm 0.75$ \\
\hline $\begin{array}{l}\text { beta-cyfluthrin } \\
\text { group } \\
(1 / 20 \text { LD50) }\end{array}$ & 57 & 29 & 11 & 97 & $19.40^{* * * *} \pm 2.82$ \\
\hline $\begin{array}{l}\text { (MO+GT) } \\
\text { group }\end{array}$ & 12 & 4 & 1 & 17 & $3.40 \pm 0.68$ \\
\hline $\begin{array}{l}\text { beta-cyfluthrin } \\
\text { group + } \\
\text { (MO+GT) } \\
\text { group }\end{array}$ & 24 & 13 & 3 & 40 & $8.00 \pm 0.71$ \\
\hline
\end{tabular}

Values are from five rats in each group and the last column represent mean \pm S.E. of micronuclei per 1000 PCEs; $\quad{ }^{* * *}$ Significant at $\mathrm{p}<0.001$

Table 2: Chromosomal aberrations induced in rats bone marrow cells after treatments

\begin{tabular}{|c|c|c|c|c|c|c|c|}
\hline \multirow[b]{2}{*}{ Treatments } & \multicolumn{4}{|c|}{ Types of structural aberrations } & \multirow{2}{*}{$\begin{array}{l}\text { Numerical } \\
\text { aberration } \\
\text { (polyploidy) }\end{array}$} & \multirow{2}{*}{$\begin{array}{c}\text { Total } \\
\text { aberrant } \\
\text { cells/ } 250 \\
\text { scored } \\
\text { metaphases }\end{array}$} & \multirow[b]{2}{*}{ Mean \pm S.E. } \\
\hline & $\operatorname{tg}$ & tb & E-E & C-T & & & \\
\hline Control group & 4 & 0 & 0 & 0 & 3 & 7 & $1.40 \pm 0.40$ \\
\hline $\begin{array}{l}\text { Beta-Cyfluthrin } \\
\text { group } \\
\text { (1/20 LD50) }\end{array}$ & 11 & 7 & 7 & 6 & 11 & 42 & $8.40^{* * * *} \pm 0.68$ \\
\hline (MO+GT) group & 3 & 0 & 0 & 0 & 1 & 4 & $0.80 \pm 0.37$ \\
\hline $\begin{array}{c}\text { Beta-Cyfluthrin } \\
\text { group + } \\
(\mathrm{MO+GT})\end{array}$ & 4 & 1 & 4 & 1 & 4 & 14 & $2.80 \pm 0.37$ \\
\hline
\end{tabular}

Values are from 5 rats in each group and the last column represent mean \pm S.E. of aberrant cells per 250 spread metaphases/treatment, $\quad * * *$ Significant at $p<0.001$; tg, chromatid gap; tb, chromatid break; E-E, end to end association; C-T, chromosomes translocation. 

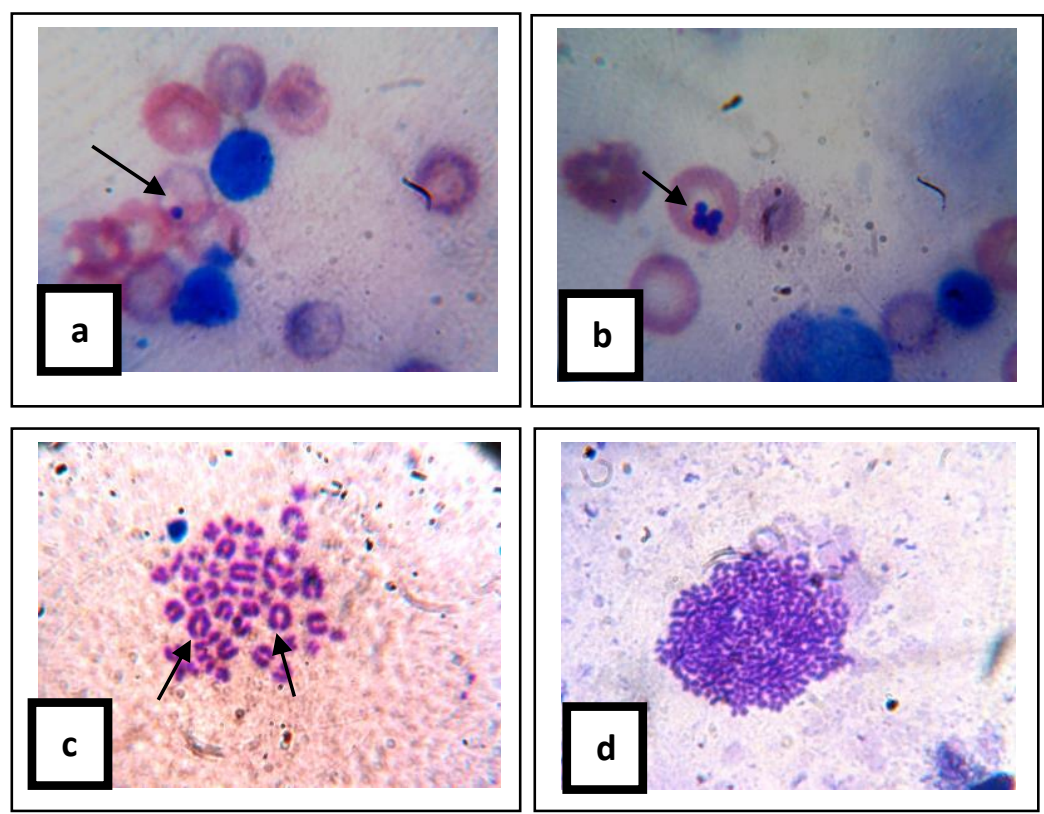

Fig (1) Light micrographs of rats bone marrow, showing (a) polychromatic erythrocytes (PCEs) with one micronucleus; (b) with four micronuclei in PCEs; (c) metaphase with end to end association (E-E); and (d) polyploidy $(>4 n)$.

In the evaluation of the adverse effects of toxic chemicals, the identification of oral acute toxicity is the first stage that offers knowledge on toxicity hazards expected from short-term exposure. The oral LD50 of the beta-cyfluthrin formulation tested here was estimated in the previous work to be $135 \mathrm{mg} / \mathrm{kg}$ b.wt in male albino rats (data not shown). Concerning the mutagenic effects of beta-cyfluthrin, the present study clearly indicated a significant induction of micronucleated polychromatic erythrocytes (PCEs) and a significant increase in the frequency of structural chromosome aberrations in the bone marrow cells of treated rats, which indicated the potential mutagenic effect of this insecticide. These results of the mutagenic study is complementary with (Ila et al., 2008) who reported that cyfluthrin showed cytotoxic effect in cultured human peripheral blood lymphocytes after 24-h of exposure while induced genotoxic effects after 48-h of cyfluthrin exposure. Recently, (Saleh et al., 2020) found the subchronic exposure (90 days) of beta-cyfluthrin with high and low doses (4.8 and $2.88 \mathrm{mg} / \mathrm{kg}$ b.wt) respectively on male albino rats, only the high dose induced mutagenic effect by a significant increase of micronuclei frequency in the normochromatic erythrocytes (NCEs) and also significant induction of oxidative stress. More addition, (Sadowska-Woda et al., 2010) studied an in vitro treatment of beta-cyfluthrin in human erythrocytes culture that resulted in induction of lipid peroxidation and significant changes in the antioxidant system. This finding about oxidative stress was confirmed before and supporting that reactive oxygen species (ROS) may be related to the adverse effects of beta-cyfluthrin. In this sense, beta-cyfluthrin exposure can stimulate the production of ROS and induces oxidative damage to essential cell components, and may be leading to DNA damage, which observed in many species. In contrast, our results not in harmony with the report $(\mathbf{E C}, \mathbf{2 0 0 2})$ that beta-cyfluthrin was not clastogenic or genotoxic in a series of in vitro and in vivo tests. To explain these inconsistent results, there are many factors may lead to these differences- Such as different sources of test 
substance, different purity, doses and times of treatment, manufacturing process and especially the cis:trans ratio of the pyrethroids. In addition, different strains and sub-strains of experimental animals must be taken into consideration (Assayed et al., 2010). On the other hand, this study demonstrates that the uptake of aqueous leaves extract of Moringa oleifera and Green tea in combination as the only source of drinking fluid had the strong ability to reduce the mutagenic effect of beta-cyfluthrin, as indicated by significant reduction in PCEs with (MNs) and structural chromosome aberrations(CAs) in bone marrow cells. The present results are consistent with (Rao et al., 2001) who observed the animals pre-treated with Moringa oleifera leave extract, and then exposed to radiation, the percentages of micronuclei and chromosome aberrations were significantly reduced. In addition, the current results are also in line with those recorded previously by (Aboelhassan et al., 2018) who confirmed the strong protective effect of Moringa oleifera leaf extract against AflatoxinB1 induced genetic alterations, and histological changes in liver and kidney of rats. More addition, (Farag et al., 2018) suggested that ethanol extract of Moringa oleifera leaves contains therapeutic and protective agents that reduced the genotoxicity induced by AflatoxinB1 in rats. Moreover, (Radwan et al., 2015) confirmed the protective and therapeutic role of Moringa oleifera leaf extract on Carbon tetrachloride (CCL4) compound which has been used in animal model to induce liver damage similar that happen by viral hepatitis in human patients. Recently, (Adeyi et al., 2020) has shown that ethyl alcohol leaves extract of Moringa oleifera has antivenom properties by healing some syndromes induced by black copra venom that finding show the extract of Moringa oleifera can be used to treat snakebites as a first aid medication or in conjunction with antivenom. The protective effect of the Moringa oleifera leaves extracts may be due to its excellent source of natural antioxidants, including vitamins, essential amino acids containing sulphur e.g. cysteine and methionine, flavonoids, minerals, kaempferol, sterols and other compounds considered to contain antioxidants and anti-inflammatory agents. The presence of its antioxidant and scavenging properties of these compounds may be a potential explanation for the protective effect of these natural products. In addition, antioxidants provide anti-mutagenic protection by scavenging reactive oxidative species (ROS) that lead to damage DNA (Sathya et al., 2010). Likewise, green tea and its main components have antioxidant and defensive properties against a wide variety of chemical toxins (Rameshrad et al., 2017) demonstrated that protective effects of green tea and its constituents were mainly attributed to their potent anti-oxidative, scavenging free radicals, chelating, anti-apoptosis and controlling inflammatory responses. Moreover, (Liu et al., 2017) assessed the potential safety of lipid soluble tea polyphenols (LSTP) from green tea extract to induce genotoxicity in mice. The results after LSTP feeding for 90 and 30 days in rats confirmed the efficacy of this substance for human dietary intake. In addition, in previous reports (Fujii et al., 2008) supported the safety of oral administration of green tea extract. Since it contains a higher concentration of phenolic monomers, ,oligomers, and a lifelong favourable source of polyphenols. Thus, the bioavailability of these polyphenols is essential, with the possibility of increased beneficial health effects. Therefore, it can be concluded from our results that Moringa oleifera and green tea in combination is consider stronger anti-mutagenic agent that has a preventive effect against ROS and consequently decrease DNA damage. These useful effects of these 
combination (MO+ GT) extract could be considered as a source of natural phytochemicals that conserve and ameliorate our health against any adverse effect of pollutants.

\section{References}

Aboelhassan, D. M., Hafiz, N. A., Darwish, H. R., Shabana, M. E., Eshak, M. G., Hassanane, M. M., Farag, I. M., A., \& Abdalla, A. M. (2018). Enhancing effects of Moringa oleifera leaf extract on carcinogenic Aflatoxin B1-induced genetic alterations, haematoxicity and histological changes in liver and kidney of rats. Bioscience Research, 15(2), 814-833.

Adeyi, A. O., Ajisebiola, B., Esther, A., Chibusi, A., \& Godwill, O. (2020). Antivenom activity of Moringa oleifera leave against pathophysiological alterations, somatic mutation and biological activities of Naja nigricollis venom. Scientific African, 8, $\mathrm{e} 00356$.

https://doi.org/10.1016/j.sciaf.2020.e00356

Adler, I. D. (1984). Cytogenetic Tests in Mammals. In in: Venitt S, Parry JM (Eds) Mutagenicity testing. A practical approach, IRL Press, Oxford (pp. 275-306.).

Anwar, F., Latif, S., Ashraf, M., \& Gilani, A. (2007). Moringa oleifera: A food plant with multiple medicinal uses. Phytotherapy Research: PTR, 21, 17-25. https://doi.org/10.1002/ptr.2023

Assayed, M. E., Khalaf, A. A., \& Salem, H. A. (2010). Protective effects of garlic extract and vitamin $\mathrm{C}$ against in vivo cypermethrin-induced cytogenetic damage in rat bonemarrow. Mutation Research, 702(1), 1-7.

https://doi.org/10.1016/j.mrgentox.2010.02.020

Chandre, F., Darriet, F., Manguin, S., Brengues, C., Carnevale, P., \& Guillet, P. (1999). Pyrethroid cross resistance spectrum among populations of Anopheles gambiae s.s. from Côte d'Ivoire. Journal of the American Mosquito Control Association, 15(1), 5359.

EC, European Commission. (2002). Review report for the active substance beta-cyfluthrin (Issue L).

http://ec.europa.eu/food/plant/pesticides/eu-pesticidesdatabase/public/?event=activesubstance. ViewReview\&id=61

El-Beshbishy, H. A. (2005). Hepatoprotective effect of green tea (Camellia sinensis) extract against tamoxifen-induced liver injury in rats. Journal of Biochemistry and Molecular Biology, 38(5), 563-570. https://doi.org/10.5483/bmbrep.2005.38.5.563

Farag, I., Roshdy, H., Radwan, H., Ghaly, I., Salah, S., Abdel-Rahim, E., \& Abdalla, A. (2018). Ameliorative role of ethanolic extract of Moringa oleifera leaf on aflatoxin $\mathrm{B}_{1^{-}}$ induced genotoxicity and biochemical alterations in rats. Journal of The Arab Society for Medical Research, 13(1), 60-70.

https://doi.org/10.4103/jasmr.jasmr_33_17

Fujii, H., Nishioka, H., Wakame, K., Magnuson, B. A., \& Roberts, A. (2008). Acute, subchronic and genotoxicity studies conducted with Oligonol, an oligomerized polyphenol formulated from lychee and green tea extracts. Food and Chemical Toxicology: An International Journal Published for the British Industrial Biological Research Association, 46(12), 3553-3562. https://doi.org/10.1016/j.fct.2008.06.005

Ila, H. B., Topaktas, M., Rencuzogullari, E., Kayraldiz, A., Donbak, L., \& Daglioglu, Y. K. (2008). Genotoxic potential of cyfluthrin. Mutation Research, 656(1-2), 49-54. https://doi.org/10.1016/j.mrgentox.2008.07.005 
Krishna, G., \& Hayashi, M. (2000). In vivo rodent micronucleus assay: protocol, conduct and data interpretation. Mutation Research, 455(1-2), 155-166. https://doi.org/10.1016/s0027-5107(00)00117-2

Liu, Z., Liu, D., Cheng, J., Mei, S., Fu, Y., Lai, W., Wang, Y., Xu, Y., Vo, T. D., \& Lynch, B. S. (2017). Lipid-soluble green tea extract: Genotoxicity and subchronic toxicity studies. Regulatory Toxicology and Pharmacology, 86, 366-373. https://doi.org/10.1016/j.yrtph.2017.04.004

Maity, S., Vedasiromoni, J. R., \& Ganguly, D. K. (1998). Role of glutathione in the antiulcer effect of hot water extract of black tea (Camellia sinensis). Japanese Journal of Pharmacology, 78(3), 285-292.

https://doi.org/10.1254/jjp.78.285

Marinowic, D. R., Mergener, M., Pollo, T. A., Maluf, S. W., \& da Silva, L. B. (2012). In vivo genotoxicity of the pyrethroid pesticide beta-cyfluthrin using the comet assay in the fish Bryconamericus iheringii. Zeitschrift Fur Naturforschung. C, Journal of Biosciences, 67(5-6), 308-311.

https://doi.org/10.1515/znc-2012-5-610

Mohafrash, S., Abdel-Hamid, H., \& Mossa, A. (2016). Adverse Effects of Sixty Days Subchronic Exposure to $\beta$-cyfluthrin on Male Rats. Journal of Environmental Science and Technology, 10, 1-12.

https://doi.org/10.3923/jest.2017.1.12

Moodley, I. (2017). Acute toxicity of Moringa oleifera leaf powder in rats. Journal of Medicinal Plants Studies, 5(5), 180-185.

Nandi, P., Talukder, G., \& Sharma, A. (1997). Dietary factor in cancer chemopreventionTitle. The Nucleus, 40, 128-144.

Noaishi, M. A., Afify, M. M. M., A., \& AbdAllah, A. A. (2013). Study the inhalation exposure effect of pesticides mixture in the white rat. Nature and Science, 11(7), 4554.

Ntila, S., Ndhlala, A., Kolanisi, U., Abdelgadir, H. and, \& Siwela, M. (2019). Acceptability of a moringa-added complementary soft porridge to caregivers in Hammanskraal, Gauteng province and Lebowakgomo, Limpopo province, South Africa. South African Journal of Clinical Nutrition, 23(3).

Radwan, H. A., Ghaly, I. S., Farag, I. M., \& Ezzo, M. I. (2015). Protective and therapeutic effect of Moringa oleifera leaf extract on DNA damage, cytogenetic changes, sperm abnormalities and high level of MDA induced by CCL4 in rats. Research Journal of Pharmaceutical, Biological and Chemical Sciences, 6, 1061-1079.

Rameshrad, M., Razavi, B. M., A., \& Hosseinzadeh, H. (2017). Protective effects of green tea and its main constituents against natural and chemical toxins: A comprehensive review. Food and Chemical Toxicology, 100, 115-137. https://doi.org/10.1016/j.fct.2016.11.035

Rao, A. V., Devi, P. U., \& Kamath, R. (2001). In vivo radioprotective effect of Moringa oleifera leaves. Indian Journal of Experimental Biology, 39, 858-863.

Sadowska-Woda, I., Wójcik, N., Karowicz-Bilińska, A., \& Bieszczad-Bedrejczuk, E. (2010). Effect of selected antioxidants in beta-cyfluthrin-induced oxidative stress in human erythrocytes in vitro. Toxicology in Vitro : An International Journal Published in Association with BIBRA, 24(3), 879-884.

https://doi.org/10.1016/j.tiv.2009.11.022

Saleh, A. Y., Eweis, E. A., Helmy, W. S. A., \& Noaishi, M. A. (2020). Evaluation of the Mutagenicity and Oxidative Stress of Beta-Cyfluthrin after Sub-chronic exposure in 
male Albino Rats. Journal of Critical Reviews, 7(18), 1870-1878.

Sathya, T. N., Aadarsh, P., Deepa, V., \& Murthy, P. (2010). Moringa oleifera Lam. leaves prevent Cyclophosphamide-induced micronucleus and DNA damage in mice. International Journal of Phytomedicine, 2(2), 147-154.

https://www.arjournals.org/index.php/ijpm/article/view/101

Verma, R., Awasthi, K. K., Soni, I., \& John, P. J. (2013). Evaluation of Cytogenetic Effects of $\beta$-Cyfluthrin in Swiss Albino Mice. 97, 168-176.

WHO. (2005). SAFETY OF PYRETHROIDS FOR PUBLIC HEALTH USE. World Health Organization (WHO) Pesticide Evaluation Scheme (WHOPES).

\section{الملخص العربى}

التأثير الوقائي للمستخلص المائي لأولق المورينجا أوليفيرا والثاي الأخضر معا ضد الطفرات التي يسببها مبيد بيتا سيفلوثرين في الفئران البيضاء

\section{محمد عبد الفتاح ابراهيم نويشي \\ المعمل المركزي للمبيدات - مركز البحوث الزراعية - مصر}

صمدت الدراسة الحالية لمعرفة تأثير الطفرات الوراثية الناتجة عن التعرض لمبيد بيتا سيفلوثرين في نخاع العظام لذكور الفئران البيضاء والدور الوقائي للمستخلص المائي للأوراق المجفقة من المورينجا أوليفيرا (MO) والثاي الأخضر (GT) معًا. وحيث ان طعم المورينجا أوليفيرا وحده مر وعشبي وغير مستساغ فإن هذا الخليط يجعل الطعم جيد ومقبول، بالإضافة الى فوائد الثاي الأخضر كمضاد

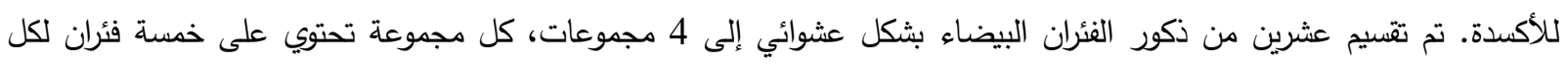

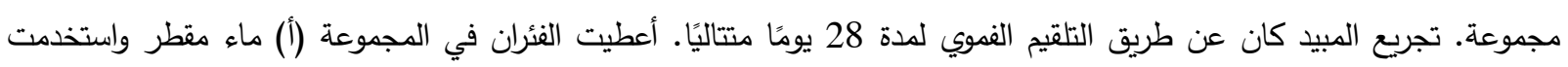

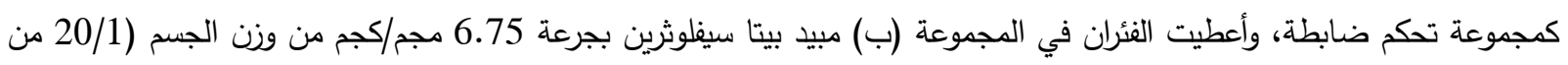
الجرعة النصفية المميتة). أعطيت الفئران في المجموعة (ج) المستخلص المائي من (MO + GT) كمصدر وحيد للسوائل الصالحة للشرب لهذه الفئران المختبرة خلال مدة التجربة (28 يومًا). أعطيت الفئران في المجموعة (د) نفس الجرعات من المجموعة (ب) بالإضافة إلى المستخلص المائي من (MO + GT) كمصدر وحيد لسائل الثرب لهذه الفئران. تم التضحية بالحيوانات بطريقة إنسانية

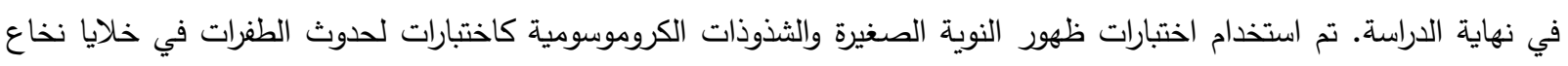
العظام. أظهرت النتائج أن إعطاء مبيد بيتا سيفلوثرين وحده أحدث زيادة معنوية (0.001 >0 م) فى تكرار الخلايا ذات النوية الصغيرة

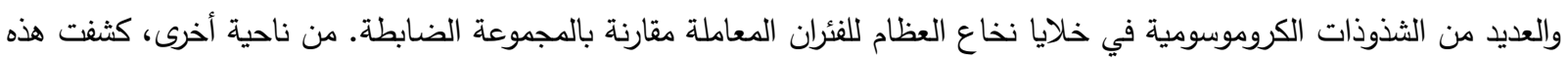

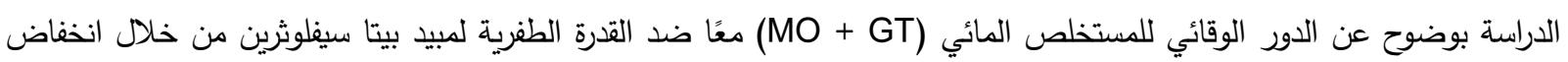

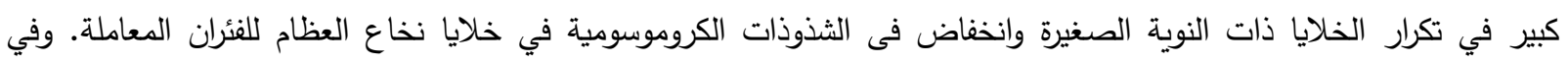

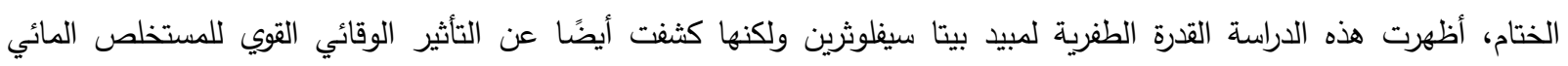

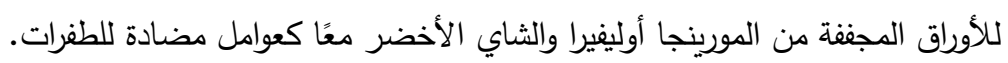

